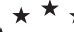

$\star$ Polityki Europejskie,

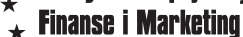

$\star \star \star 15$ (64) 2016

Emilia Gtowacka

Szkoła Główna Gospodarstwa Wiejskiego

w Warszawie

Wojciech Pizlo

Szkoła Glówna Gospodarstwa Wiejskiego

w Warszawie

\title{
Oszczędności gospodarstw domowych emerytów zamieszkujących tereny wiejskie -studium przypadku
}

\section{HOUSEHOLD SAVINGS OF PENSIONERS LIVING IN RURAL AREAS -STUDIUM CASE}

Celem artykułu jest diagnoza wielkości oszczędności gospodarstw domowych emerytów obszarów wiejskich. W pracy wykorzystano następujace metody badacze: metodę sondażu diagnostycznego, metodę obserwacji i metodę dokumentacji. Obszarem badań była wiejska gmina Dobre, $w$ powiecie mińskim. Badania empiryczne przeprowadzone zostały $w$ typowych dla tego obszaru gospodarstwach domowych emerytów. Wybór gospodarstw domowych dokonany zostat przez trzech ekspertów: przewodniczqcego Zwiqzku Emerytów, Rencistów i Inwalidów „Tęcza” w Dobrem, wójta gminy Dobre oraz lekarza z ośrodka zdrowia w Dobrem. Przeprowadzone wyniki badania wśród 9 gospodarstw domowych emerytów zamieszkujacych obszary wiejskie wskazuja, iz dochody gospodarstw domowych emerytów zamieszkujacych tereny wiejskie sq niższe, niż w pozostałych grupach spoteczno- ekonomicznych $w$ Polsce. Na podstawie struktury wydatków gospodarstw domowych emerytów stwierdzić można, że emeryci po przejściu na emeryturę zmniejszaja poziom bieżacej i przyszłej konsumpcji na rzecz zaspokojenia potrzeb zdrowotnych. Badana grupa gospodarstw domowych emerytów pomimo podeszłego wieku, niskiego poziomu wykształcenia jest grupq aktywnq na szczeblu społeczności lokalnej $i$ w sposób racjonalny stara się dysponować domowym budietem.

Słowa kluczowe: oszczędności, gospodarstwo domowe, tereny wiejskie

\section{Wstęp}

Problematyka starzenia się społeczeństwa polskiego jest coraz częściej poruszana w różnych obszarach nauk społecznych. Wzrost udziału emerytów w społeczeństwie stanowi istotne wyzwanie dla polityki socjalnej państwa. System emerytalny w dużej mierze wpływa na warunki życia jego beneficjentów. Dzieje się tak, gdyż sytuacja dochodowa gospodarstw domowych emerytów uzależniona jest od dochodów uzyskiwanych ze świadczeń emerytalnych. Gospodarstwo domowe jest najbardziej 
trwałą jednostką gospodarczą, która opiera swą działalność na własnych środkach materialnych oraz sile roboczej jego członków. Podlega ono ciagłym zmianom, które uwarunkowane są czynnikami zewnętrznymi występującymi w sferze gospodarki, społeczeństwa czy polityki państwa. Wobec tych przemian w gospodarstwach domowych przekształceniu ulegaja struktura, zakres działania oraz znaczenie poszczególnych funkcji, które spełniają gospodarstwa domowe ${ }^{1}$. Prowadzenie działalności gospodarczej jest istotą gospodarstwa domowego. Rozwój gospodarstwa domowego bazuje na zasobach materialnych oraz zasobach siły robaczej członków tego gospodarstwa. W owej działalności gospodarczej wyróżnić możemy działalność produkcyjną i usługową, zakup towarów i usług oraz w dużej mierze oszczędnościach i powiązanych $\mathrm{z}$ nimi konsumpcją ${ }^{2}$. Nadrzędnym celem działania gospodarstwa domowego staje się zaspokajanie potrzeb członków tego gospodarstwa. Każde gospodarstwo wyznacza sobie określone cele, które chce konsekwentnie realizować. Cele te zależne są od wartości jakimi kierują się domownicy oraz ich indywidualnych potrzeb, ambicji czy marzeń oraz wielkości oszczędności i dochodów bieżących jakimi dysponuje gospodarstwo domowe. W gospodarstwach domowych występuja dwa rodzaje celów: grupowe, które dotyczą wszystkich członków gospodarstwa oraz te wynikające z indywidualnych potrzeb domowników, nazywane calami jednostkowymi ${ }^{3}$.

\section{Cel i metodyka badań}

Celem pracy jest diagnoza wielkości oszczędności gospodarstw domowych emerytów zamieszkujących tereny wiejskie. W pracy wykorzystano literatury z zakresu ekonomiki gospodarstwa domowego oraz finansów. Analiza danych statystycznych została przeprowadzona na podstawie roku 2013, które stanowić mogą punkt odniesienia z uwagi na uspokojenie sytuacji gospodarczej na rynkach zagranicznych oddziaływujących na gospodarkę krajowa. Wybrane gospodarstwa domowe wskazane zostały jako typowe ${ }^{4}$ przez trzech ekspertów (1. Przewodniczącego Związku Emerytów, Rencistów i Inwalidów „Tęcza” w Dobrem, który wytypował gospodarstwa ponumerowane od 1-3,2. wójta gminy Dobre, który wskazał jako typowe gospodarstwa domowe we wsi Sołki gospodarstwa o numerach 2-6 oraz lekarz z ośrodka zdrowia w Dobrem gospodarstwa o numerach 7-9). W każdym gospodarstwie domowym wykorzystano następujące metody badawcze: metodę dokumentacji, obserwacji oraz sondażu diagnostycznego. Przeprowadzone badania spełniały wymóg metodyczny odnoszący się do triangulacji badań. W ramach badań pierwotnych wykorzystano kwestionariusz wywiadu poszerzony o wywiad swobodny, jak również metodę obserwacji i metodę dokumentacji. Wywiad tak prowadzono by respondent czuł się swobodnie i bez barier wypowiadał się na badany temat. W trakcie badań wykorzystano również metodę obserwacji, która dostarczyła istotnych informacji na temat zachowań

\footnotetext{
${ }^{1}$ A. Mazurkiewicz-Pizło, W. Pizło, Miejsce rodziny i gospodarstwa domowego w systemie społecznogospodarczym, [w:] Gospodarowanie w sadownictwie Grójca i Warki. Społeczno-ekonomiczne uwarunkowania rozwoju gospodarstw domowych, Wyd. SGGW, Warszawa 2013, s..34-35..

${ }^{2}$ A. Hodoly, Gospodarstwo domowe i jego rola społeczno-ekonomiczna, KiW, Warszawa 1971, s. 16-20.

${ }^{3}$ T. Zalega, Konsumpcja. Determinanty-teorie-modele, Wyd. PWE, Warszawa 2012, s. 81.

4 Typowym gospodarstwem domowym emerytów z obszarów wiejskich w gminie Dobre należy uznać dwuosobowe gospodarstwo domowe w którym głównym źródłem utrzymania jest świadczenie emerytalne.
} 
emerytów w obrębie własnego gospodarstwa domowego oraz ich opinii na temat otaczającego ich świata. Obszarem badań była wiejska gmina Dobre, w powiecie mińskim. Badania empiryczne przeprowadzone zostały w typowych dla tego obszaru gospodarstwach domowych emerytów.

\section{Gospodarstwo domowe jako jednostka gospodarująca}

Gospodarstwo domowe jest jednostką gospodarująca o specyficznym charakterze w porównaniu do pozostałych podmiotów gospodarczych. Odmienność ta widoczna jest w różnicach, które występują pomiędzy gospodarstwem domowym, a innymi podmiotami ${ }^{5}$. Każde gospodarstwo domowe przyjmuje sobie konkretne cele, które następnie realizuje. $\mathrm{W}$ tym tkwi, podstawowa różnica pomiędzy każdym $\mathrm{z}$ gospodarstw domowych. Natomiast działalność każdego z członków gospodarstw domowych nakierowana jest na zaspokojenie jednostkowych i zbiorowych potrzeb domowników oraz poprawę jakości życia ${ }^{6}$. Ta cecha odróżnia gospodarstwo domowe od pozostałych jednostek gospodarujących, których głównym celem jest osiąnnięcie maksymalnego zysku ${ }^{7}$. Wśród najczęściej przytaczanych definicji gospodarstwa domowego jako jednostki gospodarującej jest ta stworzona przez A. Hodoly. Według, którego gospodarstwo domowe określane jest jako „baza ekonomiczna”, którą tworzy grupa osób związanych ze sobą różnego rodzaju więziami. $\mathrm{Na}$ gospodarkę domową składa się poziom konsumpcji oraz stopa oszczędności, a także cała organizacja spożycia, a więc planowanie, podejmowanie decyzji, dostarczanie produktów, realizowanie prac $\mathrm{w}$ gospodarstwie oraz dysponowanie zasobami ${ }^{8}$. Działalność podejmowana przez gospodarstwa domowe, w głównej mierze prowadzi do zwiększenia dochodów, efektywnego zarządzania nimi $\mathrm{w}$ formie konsumpcji $\mathrm{i}$ gromadzenia poprzez oszczędzanie i inwestowanie. Działalność ta sprowadza się także do zarządzania pracą domowników ${ }^{9}$. Funkcjonowanie gospodarstwa domowego nie podlega jednakowym regułom czy zasadom, które muszą spełniać pozostałe podmioty gospodarcze, działając na zasadzie rachunku ekonomicznego. Mimo to, większość gospodarstw domowych prowadzi swój własny budżet domowy, w celu względnie racjonalnego wykorzystania swoich zasobów.

\section{Specyfika gospodarstw domowych na terenach wiejskich}

Za wiejskie gospodarstwo domowe uznaje się gospodarstwo znajdujące się na terenie jednostki administracyjnej typu wiejskiego. Do grupy tych gospodarstw należy ludność, która utrzymuje się w szczególności z pracy w rolnictwie, osób dla których rolnictwo

\footnotetext{
${ }^{5}$ T. Zalega, Konsumpcja. Determinanty-teorie-modele, Wyd. PWE, Warszawa 2012, s. 80.

${ }^{6}$ A. Mazurkiewicz-Pizło, Jakość życia gospodarstw domowych w województwie mazowieckim - ujęcie społeczno-ekonomiczne, [w:] Rynek pracy na obszarach wiejskich Mazowsza - perspektywa gender, Wyd. SGGW, Warszawa 2013, s. 131-163.

${ }^{7} \mathrm{~W}$ licznych badaniach wskazuje się, że głównym celem jest nie tylko zysk, jak napisano dla uproszczenia, ale dokładnie zysk satysfakcjonujący, wartość przedsiębiorstwa, czy też wartość dodana. Patrz szerzej A. Noga, Teorie przedsiębiorstw, wyd. PWE, Warszawa 2009, s.64-67.

${ }^{8}$ A. Hodoly, Gospodarstwo domowe i jego rola spoteczno-ekonomiczna, Wyd. KiW, Warszawa 1971, s. 20.

${ }^{9}$ W. Pizło, Gospodarowanie w sadownictwie Grójca i Warki. Społeczno-ekonomiczne uwarunkowania rozwoju gospodarstw domowych, Wyd. SGGW, Warszawa 2013, s. 32.
} 
jest dodatkowym źródłem dochodów, utrzymujących się z pracy najemnej, bądź też osób pracujących na własny rachunek, jak również emerytów i rencistów ${ }^{10}$. Pomimo, iż znajdujące się na terenach wiejskich gospodarstwa domowe różnią się pewnymi cechami, takimi jak: liczba osób w gospodarstwie, źródło utrzymania, wykształceniem czy sposobem użytkowania działki to łączy je wieś jako miejsce zamieszkania. Mieszkańcy wsi oraz tworzona przez nich grupa gospodarstw domowych uznawani są za „mikrojednostkę gospodarującą o specyficznych cechach" ${ }^{11}$. Rodzinne gospodarstwa domowe na obszarach wiejskich pojmowane są jako swoiste społeczności lokalne. Gdyż odnaleźć można w nich specyficzne cechy każdej społeczności wiejskiej, a w szczególności fakt iż większość gospodarstw domowych odczuwa więź łączącą ich z zamieszkiwanym terytorium. Członkowie wiejskich gospodarstw domowych czują przynależność do danego terytorium, silniej więc odczuwają chęć uczestnictwa w stosunkach sąsiedzkich, jak i w ogólnym oddziaływaniu na siebie oraz wspólnych relacjach ze społecznością wiejską ${ }^{12}$. Wyodrębniając specyfikę wiejskiego gospodarstwa domowego bierze się pod uwagę fakt, iż większość gospodarstw na terenach wiejskich powiazzana jest $\mathrm{z}$ gospodarstwem rolnym. Gospodarstwo domowe funkcjonując przy gospodarstwie rolnym wzajemnie się uzupełnia, wobec czego „sfera spożycia połączona

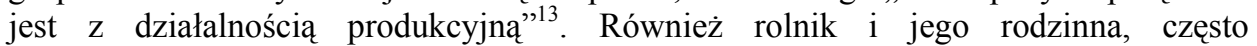
trzypokoleniowa, występują jednocześnie $\mathrm{w}$ dwóch rolach: jako członkowie gospodarstwa domowego oraz jako siła robocza w gospodarstwie rolnym. Istnieje więc silna współzależność, gdyż gospodarstwo rolne pomaga utrzymać gospodarstwo domowe, $\mathrm{z}$ kolei rodzina biorąc czynny udział i pracując $\mathrm{w}$ gospodarstwie wnosi swój udział do gospodarstwa rolnego ${ }^{14}$. Cechą charakterystyczną wiejskiego gospodarstwa domowego jest także jedność budżetu gospodarstwa, które łączy przychody gospodarstwa domowego i rolnego oraz warunkuje ich rozdysponowanie. Dochód przeznaczany jest $w$ dużej mierze na inwestycje i utrzymanie gospodarstwa rolnego oraz spożycie w gospodarstwie domowym. Z powodu nakładów poniesionych na działalność inwestycyjną w gospodarstwie rolnym, dochody na zaspokojenie potrzeb rodziny nie są stałe. Często członkowie wiejskich gospodarstw na pierwszym miejscu stawiają wydatki na polepszenie sytuacji gospodarstwa rolnego, następnie wydatki na zaspokojenie potrzeb niższego rzędu, a dopiero $\mathrm{w}$ dalszej części na zaspokojenie potrzeb wyższego rzędu ${ }^{15}$. Jest to warunek konieczny, aby gospodarstwo rolne się rozwijało i zwiększało swoją produkcję, gdyż od tego zależy sytuacja dochodowa własnego gospodarstwa domowego. Należy również pamiętać, że prace domowe i gospodarcze wykonywane są przez te same osoby, toteż trudno o rozgraniczenie czasu jaki członkowie gospodarstwa poświęcają na prace domowe i prace na roli. Trudne są zatem do ustalenia jak wiele

\footnotetext{
${ }^{10}$ K. Żelazna, Zarządzanie zasobami wiejskich gospodarstw domowych, Wyd. SGGW, Warszawa 2000, s. 18.

${ }^{11}$ K. Gutkowska, Rodzinne gospodarstwa domowe na wsi w warunkach gospodarki rynkowej, Wyd. SGGW, Warszawa 1997, s.29.

${ }^{12}$ J. Turowski, Socjologia wsi i rolnictwa, Wyd. KUL, Lublin 1995, passim.

${ }^{13}$ K. Żelazna, Zarzadzanie zasobami wiejskich gospodarstw domowych, Wyd. SGGW, Warszawa 2000, s.19.

${ }^{14}$ Przykładem może być tu rozwój gospodarstw winiarskich przedstawiony w pracy A. Mazurkiewicz-Pizło, Enoturystyka, jako szansa rozwoju społeczno-ekonomicznego obszarów wiejskich, wyd. TNOiK, WarszawaToruń, 2013, s. 225-254.

15 A. Mazurkiewicz-Pizło, W. Pizło, Rodzina i gospodarstwa domowe na obszarach wiejskich, [w:] Gospodarowanie w sadownictwie Grójca i Warki: Społeczno-ekonomiczne uwarunkowania rozwoju gospodarstw domowych, część II, Wyd. SGGW, Warszawa 2013, s. 39-47.
} 
czasu członkowie gospodarstw poświęcają pracy, a ile na czas wolny. Większość prac w gospodarstwie rolnym podlega sezonowości, a więc to pory roku decydują o tym jak dużo czasu poświęcamy na pracę w gospodarstwie rolnym. Kolejną specyficzną cechą wiejskiego gospodarstwa domowego jest częściowa niezależność od rynku produktów żywnościowych, gdyż wiele produktów gospodarstwa te wytwarzają samodzielnie.

\section{Oszczędzanie oraz decyzje inwestycyjne podejmowane w gospodarstwach domowych}

Oszczędzanie jest „zaniechaniem konsumpcji bieżącej na rzecz konsumpcji przyszłej”"16. W przypadku gospodarstw o niskich dochodach, oszczędzanie staje się koniecznością, która ma zapewnić prawidłowe funkcjonowanie. Natomiast w gospodarstwach zamożniejszych oszczędzanie przybiera formę inwestowania, gdyż zwykle oznacza odkładanie środków pieniężnych w celu zwiększenia własnego kapitału ${ }^{17}$. Cechą wspólną pomiędzy oszczędzaniem i inwestowaniem jest „konieczność rezygnacji z bieżącej konsumpcji"18. W literaturze przedmiotu wskazuje się na zależność pomiędzy poziomem zamożności danego społeczeństwa (szczególnie poziomem PKB per capita), a poziomem oszczędzania ${ }^{19}$, a także innych czynników takich jak wysokość stopy procentowej, a także nastawienie psychiczne do oszczędzania ${ }^{20}$. Oszczędzanie jest pierwotną funkcją $\mathrm{w}$ stosunku do inwestowania. J. Hirshleifer przedstawił istotę inwestycji, jako: „teraźniejsze wyrzeczenie się dla przyszłej korzyści”21. W ten sposób autor wyróżnił także dwie główne cechy oszczędzania. Są nimi: element psychologiczny, którym jest poświęcenie teraźniejszej konsumpcji na rzecz oszczędzania oraz przyszłych korzyści, które osiągnięte zostaną w przyszłości ${ }^{22}$. Należy jednak pamiętać, że decyzje o oszczędzaniu które są w danej chwili pewne i znane, w przyszłe ich korzyści są już niepewne ${ }^{23}$, bowiem obarczone są subiektywnym poziomem ryzyka odczuwanego w zależności od cech społeczno-demograficznych. Oszczędzanie, jak i inwestowanie różni się podstawowym celem, gdyż w przypadku tego pierwszego zabezpieczamy się głównie poprzez dążenie do posiadania rezerw finansowych na przyszłość, natomiast inwestując skupiamy się w szczególności na pomnażaniu kapitału. Istnieją również odmienne formy gromadzenia nadwyżek finansowych w przypadku oszczędzania i inwestowania. Instrumenty o znanej stopie zwrotu oraz o tej nieznanej, nazywane są odpowiednio bezpiecznymi i ryzykownymi. Nie tylko dochód jest uznawany za czynnik wpływający na podejmowanie decyzji związanych z

\footnotetext{
${ }^{16}$ D. Korenik, Oszczędzanie indywidualne w Polsce, AE, Wrocław 2003, s. 25-26.

17 J. Harasim, Oszczędzanie i inwestowanie nadwyżek finansowych przez ludność, [w:] Oszczędzanie i inwestowanie w teorii i praktyce, Wyd. PTE, Katowice 2010, s. 19.

${ }^{19}$ S. Białowąs, I. Olejnik, Oszczędności gospodarstw domowych w różnych fazach cyklu koniunkturalnego, Studia Oeconomica Posnaniensia 2015, vol. 3, no 4.

${ }^{20}$ B. Frączek, Analiza czynników wpływających na oszczędzanie i inwestowanie, Studia Ekonomiczne, Uniwersytet Ekonomiczny w Katowicach, 2012, nr 122, s. 92.

${ }^{21}$ J. Hirshleifer, Investment Decision under Uncertainty: Choice-Theoretic Approaches [w:] The Quarterly Journal of Economics 1965, Vol. LXXIX, No 4, s. 509.

${ }_{22}$ W. Rogowski, Rachunek efektywności inwestycji, Oficyna Wolers Kluwer Buisness, Kraków 2008, s. 14.

23 J. Harasim, Oszczędzanie i inwestowanie nadwyżek finansowych przez ludność, [w:] Oszczędzanie i inwestowanie w teorii i praktyce, PTE, Katowice 2010, s. 19.
} 
oszczędzaniem i inwestowaniem. Wielkość i struktura oszczędności każdego gospodarstwa domowego zależna jest od czynników o charakterze obiektywnym, jak i subiektywnym ${ }^{24}$. Według P. Anioły i Z. Gołasia na zachowania gospodarstw domowych w sferze oszczędności i inwestycji istotny wpływ ma siedem głównych czynników do których zaliczamy: ${ }^{25}$ dochód gospodarstw domowych, status społeczno-zawodowy głowy gospodarstwa domowego, jej wiek, wykształcenie oraz stan cywilny, jak również typ biologiczny rodziny oraz aspekty zdrowotne. O zachowaniach oszczędnościowych i podejmowaniu decyzji inwestycyjnych poza wysokością dochodu decyduje również przynależność do konkretnej grupy społeczno-zawodowej. Dzieje się tak dlatego, iż rodzaj wykonywanej pracy powiązany jest $\mathrm{z}$ wysokością wynagrodzeń, a to $\mathrm{z}$ kolei decyduje o tym jaką część dochodu chcemy przeznaczyć na oszczędności i w jakiej formie. Wraz ze wzrostem wykształcenia rośnie również świadomość finansowa. Dlatego też bardziej zamożne gospodarstwa domowe podejmują bardziej ryzykowne decyzje finansowe, niż w przypadku mniej zamożnych gospodarstw. Również wiek ma istotny wpływ na podejmowanie decyzji odnoście ryzykownych i biernych form oszczędzania środków pieniężnych. Społeczeństwo starzejące się dużo częściej wybiera produkty oszczędnościowe, które cechują się niskim stopniem ryzyka (np. depozyty bankowe, ubezpieczenia na życie czy obligacje). Wraz ze wzrostem wieku członków gospodarstw domowych wzrasta także niechęć do ryzyka ${ }^{26}$. Większą skłonnością do oszczędzania charakteryzują się rodziny z dziećmi, które chcąc zabezpieczyć ich przyszłość oszczędzają, natomiast gospodarstwa jednoosobowe, w szczególności ludzie młodzi, nie przejawiają tak dużej wagi do oszczędzania co potwierdza teoria cyklu życia rodzinnego. Pomimo stwierdzenia, iż głównym celem oszczędzania jest zabezpieczenie się na okres starości wiele gospodarstw domowych nie oszczędza wcale lub niewystarczająco licząc $w$ głównej mierze na wypłaty $z$ ubezpieczeń społecznych ${ }^{27}$. Każde z przedstawicieli gospodarstw domowych ma inny stosunek do inwestowania oraz oszczędzania. Często tradycja rodzinna oraz funkcjonowanie wśród pozostałych gospodarstw domowych wpływa na zachowanie się ich członków wobec decyzji finansowych występujących w każdym gospodarstwie ${ }^{28}$. To w jakim stopniu oszczędzamy zależy od wielu czynników. Tak samo się dzieje w przypadku motywów oszczędzania. Oszczędzać możemy z różnorakich powodów: chcąc zaspokoić własne potrzeby (np. kupno nowego samochodu czy telefonu), myśląc o przyszłości swojej rodziny (np. wybudowanie domu czy finansowanie edukacji swoich dzieci) albo chcac nieustannie pomnażać swój kapitał inwestując ${ }^{29}$. Najczęstszym motywem gromadzenia

\footnotetext{
${ }^{24}$ M. Szafrańska, R. Matysiak-Pejas, Determinanty gromadzenia oszczędności pieniężnych przez wiejskie gospodarstwa domowe, ACTA Scientiarum Polonolum, Oeconomia 9(3), 2010, s. 266.

${ }^{25}$ P. Anioła, Z. Gołaś, Zachowania oszczędnościowe gospodarstw domowych w Polsce, Wyd. Uniwersytetu Przyrodniczego w Poznaniu, Poznań 2013, s. 33-49.

${ }^{26}$ G. Rytlewska, A. Kłopocka, Wpływ czynników demograficznych na poziom i strukturę oszczędności gospodarstw domowych w Polsce, „,Bank i Kredyt” 2010 , nr.1, s. 77.

${ }_{27}$ F. Bylok, Zachowania konsumpcyjne ludzi starszych w Polsce na poczatku XXI wieku [w:] Starość $i$ starzenie się jako doświadczenie jednostek i zbiorowości ludzkich, pod red. nauk. J.T. Kowalski i P. Szukalski, Wyd. Zakład Demografii Uniwersytetu Łódzkiego, Łódź 2006, s. 92.

${ }^{28}$ B. Frączek, Analiza czynników wpływających na oszczędzanie i inwestowanie, Uniwersytet Ekonomiczny w Katowicach, nr 122/2012, s. 92.

29 J. Harasim, Oszczędzanie i inwestowanie nadwyżek finansowych przez ludność, [w:] Oszczędzanie i inwestowanie w teorii i praktyce, PTE, Katowice 2010, s. 36
} 
oszczędności jest zarządzanie gotówką, co ujawnia się w motywie transakcyjnym. Gospodarstwa domowe oszczędzają, więc by móc zarządzać własnym budżetem w celu regulowania należności. Gromadzenie oszczędności buforowych odpowiada motywowi oszczędnościowemu, a więc zabezpieczenia się na wypadek nieprzewidzianych zdarzeń w przyszłości. Trzecim motywem jest oszczędzanie na konkretny cel, łączy się więc z motywem celowości. Na szczycie piramidy przedstawiono motyw „portfelowy”, jakim jest pomnażanie majątku do czego niezbędne jest prawidłowe zarządzanie własnym kapitałem pieniężnym. Powody jakimi kierują się członkowie gospodarstw domowych gromadząc oszczędności są przedstawiane $\mathrm{w}$ różnych kombinacjach. Istotnymi czynnikami oszczędzania $w$ gospodarstwach domowych są następujące motywy: ${ }^{30}$ ostrożności (odłożenie pieniędzy na nieprzewidziane wydatki), przezorności (akumulowania zapasów w formie pieniężnej na przyszłość), wyrachowania (chęć pomnażania kapitału), poprawy (zwiększenia dobrobytu w przyszłości), niezależności (możliwość realizacji planów życiowych), przedsiębiorczości (rozwijanie się), dumy (spadku, pozostawienia majątku dla potomstwa) oraz skapstwa (jako niechęci wydawania pieniędzy). Dodatkowo M. Browing i A. Lusardi ${ }^{31}$ wskazali na nie wymieniony wcześniej motyw oszczędzania jakim jest chęć spłaty wcześniej podjętych zobowiązań finansowych.

\section{Ogólna charakterystyka społeczno-ekonomiczna badanej zbiorowości emerytów zamieszkujących gminę Dobre}

Za emerytów uznaje się grupę społeczno-ekonomiczną, która ze względu na obowiązujące prawo jest uprawniona do zabezpieczenia $\mathrm{z}$ tytułu wieku, przepracowanych lat oraz dochodów jakie uzyskała w czasie aktywności zawodowej ${ }^{32}$. Jest to zatem grupa społeczna, która za powodu upływających lat nie jest już aktywna zawodowo, tak jak reszta społeczeństwa, a głównym źródłem dochodów stają się dla niej dochody ze świadczeń społecznych, w głównej mierze emerytury. W strukturze przeciętnego miesięcznego dochodu $\mathrm{w}$ gospodarstwach domowych emerytów największy udział, bo $87,3 \%$ zajmuje dochód ze świadczeń ubezpieczeń społecznych i świadczeń pozostałych z czego, aż 82,9 \% stanowią świadczenia emerytalne. W 2013 roku $8,6 \%$ dochodów emerytów stanowily dochody z pracy najemnej, w tym również dorywczej. Świadczyć to może o tym, iż emeryci pomimo przejścia na emeryturę starają się pracować dorywczo, w celu otrzymywania dodatkowych środków na zaspokojenie potrzeb gospodarstwa domowego. Tylko $1 \%$ wszystkich dochodów emerytów stanowią dochody z pracy na własny rachunek, a niewiele, bo jedynie $0,3 \%$ stanowią dochody z własności oraz wynajmu budynków $\mathrm{i}$ budowli niezwiązanych $\mathrm{z}$ działalnością gospodarcza, jak i niewiele, bo jedynie $0,4 \%$ dochody z gospodarstwa indywidualnego $\mathrm{w}$ rolnictwie.

\footnotetext{
${ }^{30}$ J. M. Keynes, Ogólna teoria zatrudnienia, procentu i pieniądza, Wyd. Naukowe PWN, Warszawa 2003, s. 82 .

${ }^{31}$ M. Browning, A. Lusardi, Household Saving: Micro Theories and Micro Facts, Journal of Economics Literature, Vol. XXXIV, s. 1797.

${ }^{32}$ A. Kotlarska-Michalska, Starość w aspekcie socjologicznym, Roczniki Socjologii Rodziny, Tom 12 (2000), s. 148 .
} 
W wskazanej grupie typowych dla danego regionu 9 gospodarstw domowych emerytów poszukiwano ich cech wspólnych, które łączą wszystkie te gospodarstwa. Pierwsza z nich to miejsce zamieszkania, którym jest wieś. Drugim jest z kolei liczba osób tworzących gospodarstwo domowe. Wśród badanych są małżeństwa emerytów tworzących wspólne, dwuosobowe gospodarstwo domowe. Kolejnym jest wiek, który przeciętnie wynosi 73 lata (dokładnie 73,33). Najmłodszy członek badanego gospodarstwa miał 68 lat, natomiast najstarszy 87 lat. Warto również zwrócić uwagę, iż emeryci z obszarów wiejskich mają niższy poziom wykształcenia, w stosunku do emerytów zamieszkujących obszary miejskie. Jest to często uzasadnione tym, iż po ukończeniu szkoły podstawowej osoby te pomagały w rodzinnym gospodarstwie domowym nie przywiązując dużej wagi do wykształcenia. Ujawnia się to w badaniu, gdzie w omawianych gospodarstwach dominuje wykształcenie podstawowe (aż 83\%). W związku prowadzonymi badaniami gospodarstw domowych na obszarach wiejskich, warto wskazać na rodzaj pracy zawodowej jaką wykonują lub wykonywali. Dwa gospodarstwa domowe emerytów $(22,2 \%)$ posiadają własne gospodarstwo rolne, natomiast znaczna część, bo aż 7 gospodarstw $(77,8 \%)$ przekazało własne gospodarstwo rolne swoim dzieciom, bądź też zrezygnowało z prowadzenia gospodarstwa rolnego. Respondenci wskazali, iż gospodarstwa rolne (wcześniej przez nich posiadane) nie przynoszą zysków, ale i nie ponoszą dodatkowych kosztów ich prowadzenia. Emeryci prowadzący gospodarstwo rolne robią to $\mathrm{z}$ dwóch powodów: po pierwsze, aby dzięki niemu uzyskać produkty rolno-spożywcze i zmniejszyć wydatki na produkty żywnościowe, po drugie, aby mieć zajęcie zapełniając czas wolny pracami w gospodarstwie. $\mathrm{Z}$ punktu widzenia badanych respondentów we były dochody uzyskiwane z Zakładu Ubezpieczeń Społecznych (ZUS) oraz Kasy Rolniczego Ubezpieczenia Społecznego (KRUS). W badanej grupie pobierane są świadczenia zarówno z obu tych instytucji - zazwyczaj jeden emeryt w gospodarstwie domowym pobiera świadczenie z ZUS, natomiast drugi małżonek z KRUS. Wśród 9 badanych gospodarstw taka sytuacja występuje w 5 gospodarstwach, w 3 gospodarstwach oboje małżonków pobiera świadczenia z ZUS, natomiast tylko w jednym gospodarstwie oboje z członków pobiera emerytury rolnicze. Ponad połowa, bo $56 \%$ badanych gospodarstw domowych emerytów pobiera zarówno emerytury z Zakładu Ubezpieczeń Społecznych, jak i Kasy Rolniczego Ubezpieczenia Społecznego. Emerytura z ZUS, która jest wyższa od tej która jest pobierana $\mathrm{w}$ systemie rolniczym dlatego te gospodarstwa domowe swobodniej wykorzystują dochody bieżące, niż jest to w przypadku gospodarstwa, który pobiera świadczenia emerytalne jedynie z KRUS. Wśród badanej grupy 9 gospodarstw domowych emerytów największy udział stanowiły wydatki na żywność i napoje, służbę zdrowia oraz użytkowanie mieszkania i nośniki energii, odpowiednio $26,3 \%, 22,2 \%$ oraz $21,8 \%$. Wydatki na żywność oraz użytkowanie mieszkania były zbliżone do wartości wydatków ogólem dla grupy emerytów w Polsce w 2013 roku, które wynosiły odpowiednio $29,6 \%$ i $23,9 \%$. Drugą co do wielkości wartość stanowiły wydatki na służbę zdrowia, które były o 13,7 punktów procentowych wyższe od wydatków emerytów w Polsce. Nieco mniej środków pieniężnych badane gospodarstwa przeznaczają na transport i łączność $\mathrm{w}$ porównaniu do średniej dla Polski. Jest to spowodowane faktem, iż emeryci niechętnie się przemieszczają środkami transportu. Jak zaznaczaja preferują załatwiać najważniejsze sprawy podczas cotygodniowego targu, który odbywa się $\mathrm{w}$ miejscowości gminnej. W pozostałe dni starają się pozostawać $\mathrm{W}$ 
domu, gdyż podróż środkami transportu jest dla części emerytów uciążliwa. Gospodarstwa domowe emerytów w mniejszym stopniu przeznaczały swoje dochody na wydatki związane z obuwiem i odzieża, które wynoszą $4,8 \%$ co świadczy o tym, iż emeryci nie przywiązują dużej wagi ubioru, bardziej stawiając na schludny i wygodny ubiór. Najniższy udział stanowiły wydatki na kulturę i rekreację, co potwierdza jedynie, że emeryci z obszarów wiejskich nie są nastawieni na rozwój kulturalny. Wzrastający koszt $\mathrm{w}$ badanej grupie gospodarstw domowych emerytów stanowiły wydatkach na usługi medyczne oraz leki. Z powodu wzrastających cen leków oraz utrudnionego dostępu do usług medycznych, emeryci są zmuszeni przeznaczać coraz większy udział swych dochodów na usługi medyczne. Gospodarstwa domowe stają często przed wyborem zakupu żywności, czy zakup lekarstw. Sytuacja zdrowotna emerytów stale się pogarsza, co może wpłynąć w negatywny sposób na ogólną sytuację dochodową tych gospodarstw.

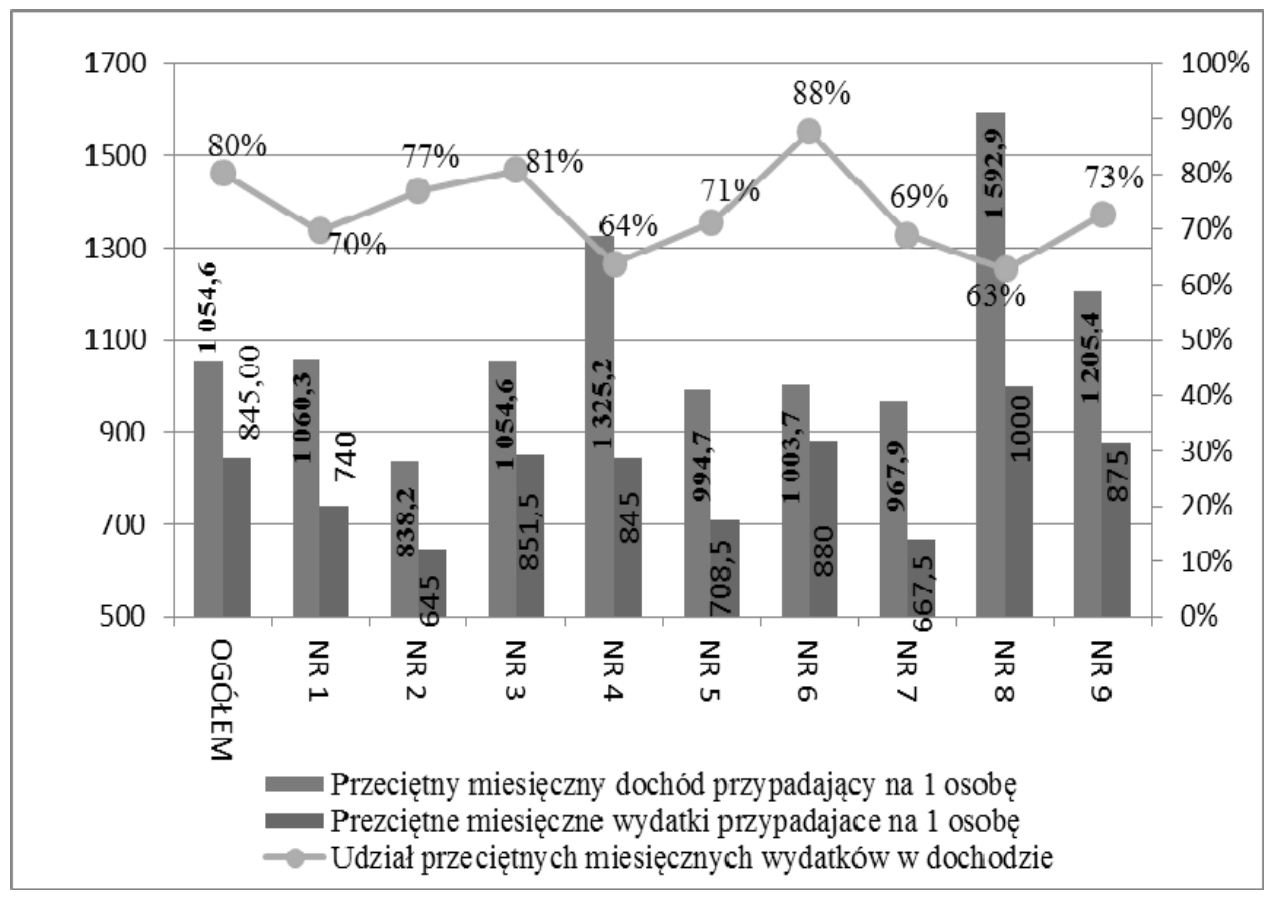

Wykres 1. Przeciętny miesięczny dochód i wydatki na 1 osobę oraz udział wydatków w dochodzie w badanych gospodarstwach domowych emerytów w 2015 roku (w zł)

Źródło: Opracowanie własne.

Procentowy udział przeciętnych miesięcznych wydatków w dochodzie przypadającym na 1 osobę $\mathrm{w}$ badanych gospodarstwach domowych waha się w przedziale od $63 \%$ do $88 \%$. Z czego przeciętny dla wszystkich badanych gospodarstw wynosi $80 \%$. Jest zatem niższy od średniej dla Polski w gospodarstwach emerytów w 2013 roku. Oznacza to, iż $\mathrm{w}$ analizowanych gospodarstwach domowych emeryci 
przeznaczają mniejszą sumę wydatków na bieżącą konsumpcję. Jest to spowodowane faktem, iż większość $\mathrm{z}$ nich odkłada zaoszczędzone pieniądze ze świadczeń emerytalnych na „czarną godzinę”. Ponad połowa badanych gospodarstw domowych emerytów oceniała swoją sytuację materialną jako ,średnią”. Natomiast 1/3, bo 33,3\% określa, że żyje im się ,źle”. Jest to wynik o 17,5\% wyższy w porównaniu do wyników badań GUS z 2013 roku odnoszących się do emerytów zamieszkujących Polskę. Z kolei jedno gospodarstwo stwierdziło, że żyje im się źle. Skupiając się na gospodarowaniu domowym budżetem przez badaną grupę emerytów zadano im następujące pytanie: Które z następujących określeń najlepiej charakteryzuje sposób gospodarowania dochodem przez Państwa gospodarstwo domowe. Wśród badanych gospodarstw domowych emerytów 1/3 twierdzi, iż żyje im się „oszczędnie i dzięki temu starcza na wszystko", jak również, że ,żyje bardzo oszczędnie, aby odłożyć na poważniejsze zakupy". Oznacza to przede wszystkim, iż członkowie tych gospodarstw ostrożnie rozporządzają domowym budżetem. Jeden z respondentów stwierdził, iż nie oszczędza na przyszłość, jak również zarządza swoim budżetem bez specjalnych wyrzeczeń. Jedynie jeden z respondentów ocenił zarządzanie swoim budżetem jako „trudne, gdyż pieniędzy starcza jedynie na najtańsze jedzenie, ubranie oraz najpotrzebniejsze opłaty”.

\section{Oszczędności w badanej grupie gospodarstw domowych emerytów}

Analizując gospodarowanie domowym budżetem przez badaną grupe gospodarstw domowych emerytów należy przyjrzeć się oszczędnościom jakie posiadają. Oszczędności po przejściu na emeryturę stają się nie tylko środkiem zaspokajającym potrzeby konsumpcyjne gospodarstw domowych. Członkowie gospodarstw domowych myśląc przyszłościowo traktują oszczędności jako rezerwę na zdarzenia losowe. Odkładają pieniądze w celu zabezpieczenia rodziny w momencie choroby lub śmierci. Według wszystkich gospodarstw domowych oszczędzanie na konkretny cel jest trudne do realizacji. Oszczędności w badanych gospodarstwach domowych są w znacznym stopniu uzależnione od dochodów jakie one uzyskują. Określają one jak długo gospodarstwo domowe jest $\mathrm{w}$ stanie funkcjonować $\mathrm{w}$ momencie nieotrzymywania żadnych środków pieniężnych. W badanych gospodarstwach domowych emerytów poziom oszczędności jest stosunkowo niski w stosunku do średniej Polski. Wśród badanych gospodarstw domowych emerytów tylko jedno spośród wszystkich dziewięciu posiada oszczędności powyżej półrocznych - do rocznych. Z kolei, 4 gospodarstwa posiadają oszczędności jedynie do wysokości miesięcznych dochodów gospodarstwa, co wpływa negatywnie na zaspokojenie potrzeb wyższego rzędu, czy nieoczekiwanych zdarzeń. Tyle samo gospodarstw domowych posiada oszczędności powyżej miesięcznych - do 3 miesięcznych dochodów gospodarstwa domowego, co również nie zapewnia bezpieczeństwa materialnego wśród badanej grupy emerytów. Badana grupa emerytów nie zabezpiecza swoich oszczędności w postaci obligacji, funduszy inwestycyjnych, czy polis ubezpieczeniowych. W przeważającej mierze gospodarstwa domowe emerytów gromadzą swoje oszczędności w postaci gotówki. Osiem z dziewięciu badanych gospodarstw domowych posiada oszczędności jedynie $\mathrm{w}$ formie gotówki. Większość z nich traktuje taki sposób oszczędzania w tzw. „skarpetę” jako najbardziej bezpieczny. Niektórzy $\mathrm{z}$ nich przyznają się, że zmieniają miejsca przechowywania gotówki w swoim domu. Często zdarza się, że miejsca te są dość 
oryginalne, np. wazon, kieliszki, łóżko czy nawet poszewki na poduszki. Zdarza się również, iż przechowywanie oszczędności $\mathrm{w}$ tak wielu miejscach sprawia trudności z określeniem konkretnej kwoty jaką aktualnie dysponują. Jedynie w jednym gospodarstwie domowym oszczędności są przechowywane w bankach. Oznacza to niskie zaufanie badanych respondentów do instytucji bankowych. Ponad połowa gospodarstw domowych badanej grupy emerytów nie posiadają konta w banku i nigdy nie korzystali z jego usług. Jedynie cztery gospodarstwa na dziewięć posiadają konto w banku, ale najczęściej z powodu otrzymywania na nie emerytury, a wcześniej pensji.

W gospodarstwach domowych emerytów deklarowane były różne cele na które gospodarstwa domowe gromadzą swoje oszczędności. Do najbardziej popularnych celów na które badane gospodarstwa domowe przeznaczają swoje oszczędności zalicza się leczenie i rezerwy losowe (wykres 2). Największa ilość oszczędności, bo aż w 8 gospodarstwach domowych przeznaczana jest na cele związane $\mathrm{z}$ leczeniem oraz rezerwę na sytuacje losowe. Sześć gospodarstw domowych przeznacza swoje oszczędności na wydatki konsumpcyjne, opłaty stałe, remont domu oraz zabezpieczenie na okres starości. Tylko jedno spośród dziewięciu gospodarstw domowych przeznacza swoje oszczędności na wypoczynek. Wynika z tego, że wśród badanych gospodarstw domowych emeryci nie czują potrzeby odpoczynku czy wyjazdów na wakacje lub też nie mają na ten cel wystarczająco dużo środków pieniężnych.

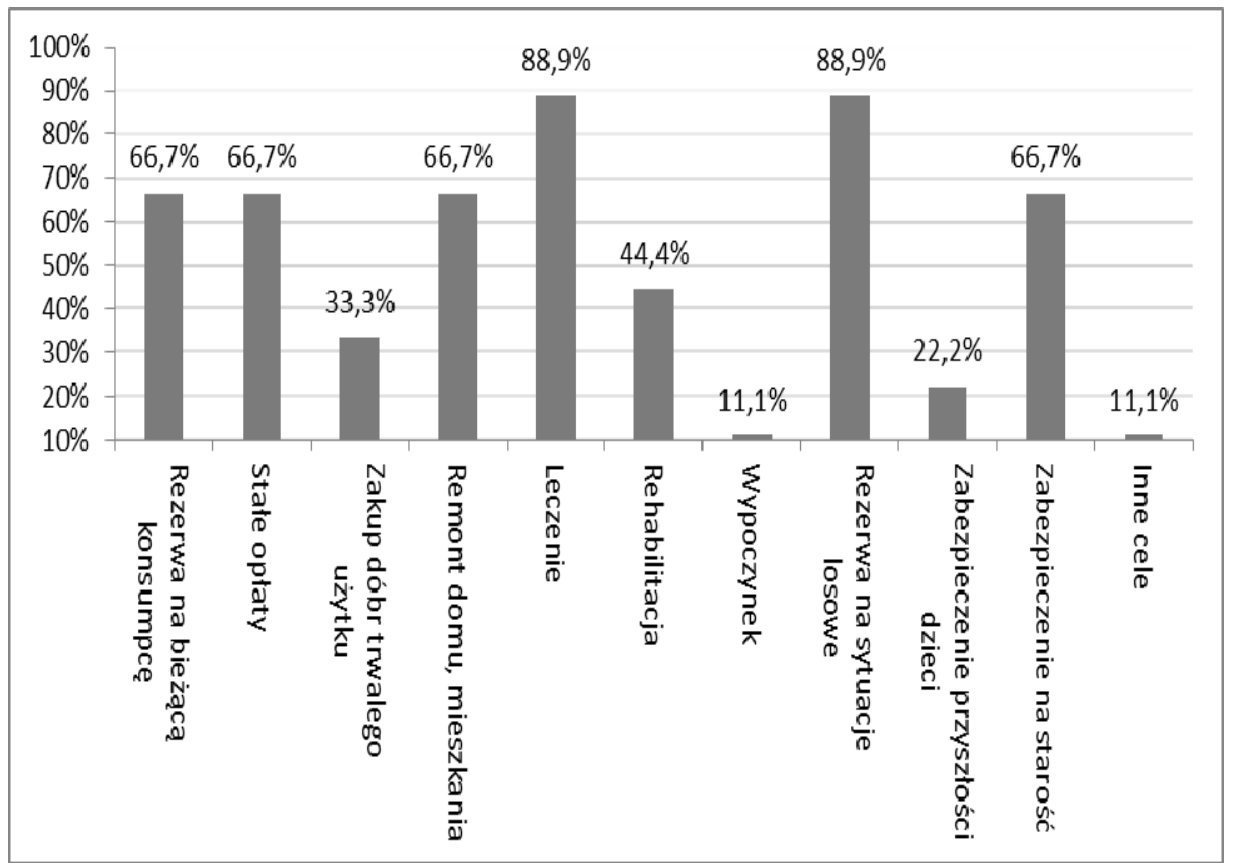

Wykres 2. Cele na które gospodarstwa domowe emerytów gromadzą oszczędności Źródło: Opracowanie własne. 


\section{Podsumowanie i wnioski}

Wyniki badań pozwoliły określić strukturę dochodów i wydatków badanej grupy gospodarstw domowych emerytów zamieszkujących tereny wiejskie oraz odpowiedzieć na pytanie jak wygląda sytuacja społeczna tych gospodarstw. Z analizy danych GUS dotyczących dochodów gospodarstw domowych emerytów w Polsce wynika, iż emeryci są drugą po osobach pracujących na własny rachunek grupą społeczno-ekonomiczną uzyskującą najwyższe dochody. Jest to spowodowane głównie faktem, iż gospodarstwa domowe emerytów są zwykle gospodarstwami dwuosobowymi, w skutek czego dochód dzielony jest na mniejszą liczbę osób, niż w przypadku pozostałych grup zawodowych.

Przeprowadzone wyniki badania wśród 9 gospodarstw domowych emerytów zamieszkujących obszary wiejskie wskazują, iż dochody gospodarstw domowych emerytów zamieszkujących tereny wiejskie są niższe, niż w pozostałych grupach społeczno- ekonomicznych w Polsce. Dochód rozporząadzalny na 1 osobę wśród emerytów w Polsce odbiega od wyników osiągniętych wśród badanej grupy emerytów na obszarach wiejskich. Wśród badanej grupy emerytów zamieszkujących gminę Dobre przeciętny miesięczny dochód na 1 osobę wynosił 1054,62 zł. Był zatem o 18,25\% niższy w stosunku do średniej dla wszystkich gospodarstw domowych w Polsce w roku 2013 oraz aż o $24,83 \%$ od dochodu uzyskiwanego przez przeciętnego polskiego emeryta w 2013 roku. Na podstawie struktury wydatków gospodarstw domowych emerytów stwierdzić można, że emeryci po przejściu na emeryturę zmniejszają poziom bieżącej i przyszłej konsumpcji na rzecz zaspokojenia potrzeb zdrowotnych. Owa specyfika wydatków gospodarstw domowych emerytów przejawia się głównej mierze obserwując wydatki ponoszone na służbę zdrowia wśród emerytów w Polsce, które znajdują się na trzecim miejscu osiagając wartość $8,5 \%$, w momencie gdy dla średniej dla Polski wynosiły jedynie $5,1 \%$. Wśród badanej grupy gospodarstw domowych emerytów w gminie Dobre drugą co do wielkości wartość w strukturze wydatków stanowiły wydatki związane ze służbą zdrowia, które wynosiły $22,2 \%$. Były one o $13,7 \%$ wyższe niż wydatki przeciętnego polskiego emeryta. $Z$ powodu stale wzrastających cen leków i usług medycznych, emeryci są zmuszeni coraz większą wartość swoich dochodów przeznaczać na służbę zdrowia, stając często przed wyborem zmniejszenia bieżącej i przyszłej konsumpcji na rzecz wykupu lekarstw. Z badań wynika także, iż badana grupa gospodarstw domowych emerytów ostrożnie dysponuje domowym budżetem, aby zaoszczędzić na wydatki nieprzewidywalne, rzadziej na zaspokojenie potrzeb konsumpcyjnych wyższego rzędu. Członkowie gospodarstw domowych po przejściu na emeryturę posiadają dużo więcej czasu wolnego, aniżeli pozostałe grupy zawodowe. Emeryci z obszarów wiejskich dzięki nieustannemu kontaktowi ze społecznością lokalną oraz życiu $\mathrm{w}$ zgodzie $\mathrm{z}$ naturą są pomimo pogarszającego się stanu zdrowia, czy świadczeń emerytalnych jakie uzyskują pozytywnie nastawieni do sytuacji życiowej w której się znajdują. Badana grupa gospodarstw domowych emerytów pomimo podeszłego wieku oraz niskiego poziomu wykształcenia jest grupą aktywną na szczeblu społeczności lokalnej i w sposób racjonalny stara się dysponować domowym budżetem. Należy również pamiętać, iż poprawa sytuacji materialnej emerytów, która dotyczy wzrostu wypłacanych emerytów w skutek corocznej waloryzacji wciąż nie jest satysfakcjonująca, aby mówić o dobrej sytuacji tej grupy społeczno - ekonomicznej. 


\section{Bibliografia}

1. Anioła P., Gołaś Z., Zachowania oszczędnościowe gospodarstw domowych w Polsce, Wyd. Uniwersytetu Przyrodniczego w Poznaniu, Poznań 2013, s. 33-49.

2. Białowąs S., Olejnik I., Oszczędności gospodarstw domowych w różnych fazach cyklu koniunkturalnego, Studia Oeconomica Posnaniensia 2015, vol. 3, no 4.

3. Browning M., Lusardi A., Household Saving: Micro Theories and Micro Facts, Journal of Economics Literature, Vol. XXXIV, s. 1797.

4. Bylok F., Zachowania konsumpcyjne ludzi starszych w Polsce na poczatku XXI wieku [w:] Starość i starzenie sie jako doświadczenie jednostek i zbiorowości ludzkich, pod red. nauk. J.T. Kowalski i P. Szukalski, Zakład Demografii Uniwersytetu Łódzkiego, Łódź 2006, s. 92.

5. Frączek B., Analiza czynników wpływających na oszczędzanie i inwestowanie, Studia Ekonomiczne, Uniwersytet Ekonomiczny w Katowicach, 2012, nr 122, s. 92.

6. Gutkowska K., Rodzinne gospodarstwa domowe na wsi w warunkach gospodarki rynkowej, Wyd. SGGW, Warszawa 1997, s.29.

7. Harasim J., Oszczędzanie i inwestowanie nadwyżek finansowych przez ludność, [w:] Oszczędzanie i inwestowanie w teorii i praktyce, PTE, Katowice 2010, s. 19.

8. Hirshleifer J., Investment Decision under Uncertainty: Choice-Theoretic Approaches [w:] The Quarterly Journal of Economics 1965, Vol. LXXIX, No 4, s. 509.

9. Hodoly A., Gospodarstwo domowe $i$ jego rola spoleczno-ekonomiczna, Wyd. KiW, Warszawa 1971, s. 20.

10. Keynes J. M., Ogólna teoria zatrudnienia, procentu i pieniądza, Wyd. Naukowe PWN, Warszawa 2003, s. 82.

11. Korenik D., Oszczędzanie indywidualne w Polsce, AE, Wrocław 2003, s. 25-26.

12. Kotlarska-Michalska A., Starość w aspekcie socjologicznym, Roczniki Socjologii Rodziny, Tom 12 (2000), s. 148.

13. Mazurkiewicz-Pizło A., Enoturystyka, jako szansa rozwoju społeczno-ekonomicznego obszarów wiejskich, wyd. TNOiK, Warszawa-Toruń, 2013, s. 225-254.

14. Mazurkiewicz-Pizło A., Jakość życia gospodarstw domowych w województwie mazowieckim - ujęcie społeczno-ekonomiczne, [w:] Rynek pracy na obszarach wiejskich Mazowsza - perspektywa gender, Wyd. SGGW, Warszawa 2013, s. 131-163.

15. Mazurkiewicz-Pizło A., W. Pizło W., Rodzina i gospodarstwa domowe na obszarach wiejskich, [w:] Gospodarowanie w sadownictwie Grójca i Warki: Społeczno-ekonomiczne uwarunkowania rozwoju gospodarstw domowych, część II, Wyd. SGGW, Warszawa 2013, s. 39-47.

16. Mazurkiewicz-Pizło A., Pizło W., Miejsce rodziny i gospodarstwa domowego w systemie społeczno-gospodarczym, [w:] Gospodarowanie w sadownictwie Grójca i Warki. Społecznoekonomiczne uwarunkowania rozwoju gospodarstw domowych, Wyd. SGGW, Warszawa 2013, s..34-35.

17. Noga A., Teorie przedsiębiorstw, wyd. PWE, Warszawa 2009, s.64-67.

18. Rogowski W., Rachunek efektywności inwestycji, Oficyna a Wolers Kluwer Buisness, Kraków 2008, s. 14

19. Rytlewska G., Kłopocka A., Wpływ czynników demograficznych na poziom i strukturę oszczędności gospodarstw domowych w Polsce, „Bank i Kredyt” 2010 , nr.1, s. 77.

20. Szafrańska M., Matysik-Pejas R., Determinanty gromadzenia oszczędności pieniężnych przez wiejskie gospodarstwa domowe, ACTA Scientiarum Polonolum, Oeconomia 9(3), 2010, str.266.

21. Turowski J., Socjologia wsi i rolnictwa, Wyd. KUL, Lublin 1995, passim.

22. Zalega T., Konsumpcja. Determinanty-teorie-modele, Wyd. PWE, Warszawa 2012, s. 80.

23. Żelazna K., Zarządzanie zasobami wiejskich gospodarstw domowych, Wyd. SGGW, Warszawa 2000, s. 18. 


\section{Summary}

The aim of the article is to diagnose the size of the household savings pensioners in rural areas. The study used the following methods researchers: diagnostic survey method, observation method, and the method of documentation. The area of study was the rural municipality good, in the district of Minsk. Empirical studies were carried out in the typical for this area households of retirees. Selection of households was made by three experts: President of the Union of Pensioners and Disabled "Rainbow" in the Good, the Commune and the good doctor from the health center in Dobre. Carried out the test results of 9 households of retirees living in rural areas indicate that household income of pensioners living in rural areas are lower than in other socio-economic groups in Poland. Based on the structure of household expenses of retirees tell you that pensioners after retirement reduce the level of current and future consumption to meet health needs. The study group households of retirees in spite of old age, low educational level is a group active at the community level and in a rational way is trying to have a household budget.

Key words: savings, household, rural area

\section{Informacje o autorze:}

Dr hab. inż. Wojciech Pizlo

Szkoła Główna Gospodarstwa Wiejskiego

w Warszawie

Wydział Nauk Ekonomicznych

ul. Nowoursynowska 166,

02-787 Warszawa

e-mail: wojciech_pizlo@sggw.pl

Emilia Głowacka

Katedra Polityki Europejskiej, Finansów Publicznych i Marketingu

Wydział Nauk Ekonomicznych SGGW 